the practice of this unique and creative mode of expression that continues on its comeback trail in Pakistan.

Furrukh Khan

doi:10.1057/palgrave.fr. 9400307

\title{
Social choreography: ideology as performance in dance and everyday movement
}

Andrew Hewitt; Duke UP, Durham and London, 2005, ISBN082233502X f54.00 (Hbk)

Social Choreography, despite the dancers on its cover, is not about the disposition of performing bodies in space, or about the stamp of individual creativity on movement. The term 'choreography' has a broader scope in Andrew Hewitt's contribution to the series (titled Post-Contemporary Interventions) edited by Stanley Fish and Fredric Jameson. Dance, Hewitt argues, merely heightens the conventionalization of the body's movements, which suggests the possibility that all the body's ways of relating to other bodies and to meaning are to be placed along a continuum of gestures more or less aestheticized or constructed. The theorist of social choreography then (choreography is also defined as an approach to reading movement), undertakes to map the rimlands - the shifting zone of articulation - between discourse and bodily practice, ideology and performance. Hewitt himself invokes not only Isadora Duncan, Ted Shawn and Nijinsky, but also Ruskin, Balzac, Bergson and Delsarte, to reflect on the ways in which both dance and the quotidian choreography of the walk, of social gesture, and of posture have sought - and have repeatedly failed - to render the bourgeois body legible.

At the historical moments Hewitt selects for particular attention, dance emerges as an embodied forecast of, or model for, social relations. These moments are loosely bound together by a process of modernization, by a telos of technological rationalization and by the cultural contradictions unleashed by capitalist relations. In Chapter 1, for instance, Hewitt tracks the relationship between dance and philosophical approaches to the idea of labour. While Schiller saw the English ballroom as representing the ideal alignment of individual freedom (play) and social harmony, Ruskin and Morris (whose discourse on art, work and play is summed up by the phrase 'aesthetic socialism') assimilated dance to the sphere of work: an idea that, given 19th century vitalist faith in an originary 'social energy,' had its dangers. The 
menace of dance lay in its affinity with the 'physiological sublime,' which, Hewitt suggests, was a mode of social choreography linked to vitalism and the new forms of mass culture. In Ruskin's view, the physiological sublime was the ideology of industrial capitalism in embodied form. The subject who pursued it would become a vehicle for pure vital energy (of work or the instinct for activity; of primal forces, including the sexual), losing the boundaries and definition - the skin - that critical reflection alone could give him. Ruskin pictured this subject as Marsyas, channel of the wind's music, and the water's, released from the limits of sociality and reflexivity into death, flayed by Apollo, god of intellectual music.

Whereas high art invited the spectator to reflect critically and rationally on the conjunction of proficiency and transcendence/morality, popular culture, even in Ruskin's time, was a performance of will-less entertainment, the song of Marsyas, the foreshadowing of Taylorism. Little wonder, then, that Ruskin read the can-can as one of the great scandals of his time. Hewitt points out that in Ruskin's example of men rowing, lack of skill (atechnia) is itself a lack of morals (amoria); but the 'can-can from hell' demonstrated through highly sexualized female bodies that brilliant technique (i.e., machine-like rationalization) could be distressingly coupled with amorality, seducing the spectator into uncritical, unreflective immersion. The can-can was the flip side of dance-as-work: it was dance-for-sale, dance-as-will-less automation, dance that made the aesthetic socialists 'darkly aware' of the wound of commodification and the reification of human labour. Paradoxically, while dance was celebrated by some Victorians as the utopian enactment of a positive social energy and of the abstraction now called 'labour power,' it was also becoming an aesthetic model for the technological rationalization (in its most simplified form, a relationship between bodies, rhythmic movement and time) that ultimately led to automation and efficiency.

Hewitt only examines the gendering of social choreography in passing. Nevertheless, his conceptual framework opens up a world of possibilities for a more gender-specific or feminist analysis of performance. In the chapter on Delsarte, for instance, Hewitt suggests that the promenade or brisk walk is the bourgeoisie's ultimate form of choreographed self-codification. One would imagine that the bourgeois promenade in its formative phase was inevitably gendered (by clothing if by nothing else): Hewitt's analysis of walking as gesture could be extended to include its gender-differentiated manifestations. The chapter on Isadora Duncan, similarly, could be a blueprint for a reading of the intertwined effects of dance, heresy, reaction and nation-formation. The case of Rukmini Devi and India, for instance, parallels Duncan and America in so many respects that Hewitt's suggestive reading of Duncan could be the starting point for a more gender-inflected analysis of the female performer as embodying and engendering the nation. 
The final chapter of Social Choreography suggests other links between gender, performance and capitalism. As German avant garde dancers of the 1920s, rapt in the pursuit of an elusive transcendence, disavowed technological rationality, the Tiller Girls performed this inescapable feature of modernity. They captured the German aesthetic imagination as no other form of art did at this point, Hewitt notes, because they rendered in movement the economic and technological triumphalism of a new (American) order. The Girls, revealing all, concealing nothing, caused no scandal, desire being deferred and dispersed along the chain of perfectly coordinated, athletic, machine-like legs. Their success marked the splitting-off of popular culture from high culture, of cheerfully high-stepping Girl from mysterious and haunting Woman (sign of mystery, concealment of the disavowed, scandal, desire, the political unconscious). This spectacle of rationalization ('a pure assemblage of lines') continued to be a hit with German audiences well into the 1930s, long after the bubble of American promise had been pricked. This fact caused critics like Siegfried Kracauer to reflect on the historical necessity of a dance that does not organically relate to its context, that is an abstraction, which, in fact, performs a break with the idea of representation as the key term in a critique of ideology. Hewitt reads Kracauer's observations as a seminal breakthrough in ideologycritique, since they demonstrate how ideological reproduction, no longer tied to mode of production, can become a world unto itself (relatively autonomous and non-referential). German girlkultur then, brings social choreography - as method - into being.

Hewitt stages his argument about social choreography's role within modernity as a sort of battle between the body as instrument of referentiality and the body as performative. Having established that ideology does not lie in consciousness alone (this is a little puzzling: isn't the false consciousness model of cultural production a historical curiosity by now?), and having suggested that Jameson's model of the political unconscious could be extended beyond the symbolic, Hewitt proposes that we do something new if we want to see the political unconscious performed: manwatch.

Performance implies non-referentiality; non-referentiality emphasizes the relative autonomy of the cultural sphere. Thus, the body as performing entity seems to be invoked in the service of a dialectical relation between choreography (ideological reproduction) and social relations (Hewitt is elliptical on this one: is one to equate it with 'mode of production'?). Whereas viewing the body as instrument of the symbolic, metaphorical, and mimetic suggests that its gestures merely reflect social relations, the larger theoretical point Hewitt wishes to emphasize is that choreography enacts the fantasies that underpin social relations, or more radically, that it produces or shapes social relations. Although Hewitt disavows the 'idealist' intention of deriving social relations from 
aesthetics, he is certainly tempted by the idea of choreography as a 'rehearsal' for intersubjectivity and politics.

Hewitt offers brilliant, tantalizing flashes of insight into dance history (the connections between ballet, specularity, authoritarian feudal structures and gender come to mind) that are in themselves exemplars of materialist reading, but he clearly feels no interest in this referential route to an understanding of modernity. Turning away from the body as metaphor, Hewitt dwells on the drama of the irreducibly performative body bursting through the constraints of semiosis. He lines up the deconstructive moments: the man in Bergson's essay stumbling, Isabella Duncan observing that America made her sick (the literal enactment of hatred towards the abject bodies of non-whites, and towards their artistic heritage), crazy Nijinsky bleeding from a cut foot. The intrusion of the bodily (not as some metaphysical guarantee of materiality, but as, literally, fallibility) in the stumble or the Tourettist gesticulation prevents the completion of the bourgeois project of legibility in everyday social choreography, and reveals the constructedness of the ideologically marked body.

In one sense, of course, despite his insistence on the performative, as if the act of reading itself could be infected by this connection, and despite the invention of a new name for this method, Hewitt is 'literarizing' with a vengeance. He honours even his symptomatic embodied moments more in the text than in the performance. What he examines, in effect, is a 'tradition of thinking about social order that derives its ideal from the aesthetic realm and seeks to instill that order directly at the level of the body' (3, emphasis mine). High art, according to Hewitt, develops in the widening rift between the rationalized, technically flawless and finished performance on one side and the somatically inept spectator on the other. Social choreography as method, one might equally well argue, develops out of a further rift: between that spectator in the gallery and the vantage point of the exquisitely self-conscious theorist who gives his attention not to the dance, but to the spectator. We are reading Bergson reading laughter; and because we are reading it, even at one remove, the body has turned into something that 'stands for something else.' The 'something else' now represented by the body is not utopian totality, transcendence or unrestricted self-presence. Hewitt's purpose is not to reveal an alternative truth, but to point the moral that there is no truth except instability, ideology, productivity. The body can experience the ideology of ballet as pain, but the body cannot produce the 'truth' (as Duncan claimed it could) that can break down ideology; it can only embody a different ideology (for instance, the ideology of America as the end of ideology).

doi: $10.1057 /$ palgrave.fr. 9400308

Srividya Natarajan 